\title{
PARASTĀS IEVAS ZIEDĒŠANA LATVIJĀ PIRMS UN PĒC 100 GADIEM
}

\author{
Gunta Kalvāne, Andis Kalvāns \\ Latvijas Universitāte, G̦eogrāfijas un Zemes zinātṇu fakultāte, \\ e-pasts: Gunta.kalvane@lu.Iv, Andis.kalvans@lu.Iv
}

\begin{abstract}
Anotācija. Fenologiiskie dati bieži izmantoti klimata mainības pētījumos, gan rekonstruējot pagātnes klimatu, gan arī novērtējot nākotnes klimata iespējamo ietekmi. Pētījumā analizēti ilgtermiṇa parastās ievas Padus racemosa ziedēšanas dati Latvijā, kā arī modelētas iespējamās ievas ziedēšanas pārmaiṇas nākotnē, izmantojot grādu dienu (aktīvas temperatūras summas) modeli un ENSEMBLES klimata datu kopu. Pēdējos 50 gados ievas ziedēšanas vidējās vērtības ir mainījušās nedēlas intervālā - ieva zied agrāk. Negatīva ziedēšanas tendence ir sagaidāma arī nākotnē: modeḷa dati rāda, ka ievas ziedēšanas sākums tālajā nākotnē var mainīties 3 nedēḷu intervālā un ievas ziedēšana Latvijas teritorijā 21.gs. beigās tiks fiksēta jau aprīḷa trešajā dekādē nevis maija otrajā dekādē kā mūsdienās.
\end{abstract}

Atslēgas vārdi: parastā ieva, Padus racemosa, fenolog̣ija, fenoloǵiskā modelēšana, grādu dienas, Latvija.

Ievads

Lapu plaukšanas sākums, ziedēšanas, aug̣̣u nogatavošanās fāzes ir fitofenologijas izpētes objekts. Dabas ritmu novērošana - fenologiija - ir viena no senākajām dabas zinātṇu nozarēm. Pirmās fenoloǵiskās norādes atrodamas gan Bībelē, gan seno romiešu dzejnieku tekstos, vissenākie pierakstītie dati ir saglabājušies Japānas imperatoru dārzu arhīvos, kur ķiršu ziedēšanas sākums kā pavasara atnākšanas festivālu laiks datēts no 705. gada mūsu ērā (Kalvāne 2011).

Arī Latvijā ir senas fenoloǵiskās tradīcijas, darba ritms tika pielāgots dabas kalendāram un mēneši tika saukti par lapu mēnesi, siena mēnesi u.tml. Pirmie zināmie dati atrodami vācu mācītāju dienasgrāmatās un Rīgas dabas pētnieku biedrības rakstu krājumos (Zirnītis 1956) no 19.gs. sākuma, savukārt sistemātisks novērotāju tīkls Latvijas teritorijā izveidots 1926. gadā, kurš ar mainīgām sekmēm darbojas līdz mūsdienām.

Fenoloǵiskie dati tradicionāli izmantoti lauksaimniecībā, taču pēdējā laikā arvien biežāk vēsturiskos fenologiskos datus izmanto klimata mainības pētìjumos, jo "augi un

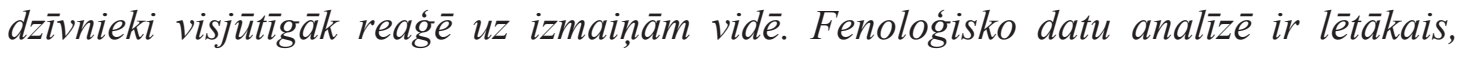
èrtākais, vieglākais veids, kā pamatot klimata mainību" (Koch et al. 2009).

"Dabas dzìves novērojumi ḷauj spriest par vietējo klimatu. Tas iespējams tādēl, ka dzīvnieku un augu attīstības gada cikls atrodas ciešā sakarībā ar vietas laika apstākliem. Dzīvais augs ar saviem attīstības fāzu momentiem kā spogulī rāda noteiktās vietas 
klimatiskos apstāklı $s^{\text {“" }}$ - tā par fenoloǵisko novērojumu nozīmi raksta A. Zirnītis (1956), kurš 20.gs. 60. gados veicis fenoloǵisko datu analīzi Latvijas teritorijai.

Fenoloǵiskie dati tiek izmantoti gan pagātnes klimata rekonstrukcijā, gan arī nākotnes projekcijās.

Pētījumā analizētas parastās ievas Padus racemosa - bieži sastopama un viegli atpazīstama krūma - ziedēšanas pārmaiņas Latvijas teritorijā laika periodā no 1927. līdz 2016. gadam, izmantojot brīvprātīgo novērotāju datus, kā arī, lietojot aktīvās temperatūras summas modeli, raksturotas ievas ziedēšanas tendences tālajā (līdz 2100. gadam) nākotnē.

\section{Materiāli un metodes}

Fenologiskie dati. Pētījuma pamatā ir brīvprātīgo novērotāju dati, kas iegūti visā Latvijas teritorijā. Fenoloğiskie dati digitalizēti no "Dabas un vēstures kalendāra" (no 2005. gada Daba un vēsture) (periodam no 1973. līdz 2016. gadam), Fenologiskajiem bil̦eteniem (1959.-1972. gads), Fenologiskajiem bukletiem (1927.-1935. gads). Datu analīzē izmantotas A. Zirnīša (1956) fenologíisko datu tabulas laika periodam no 1927. līdz 1940. gadam, kur atspoguḷotas 58 novērojumu punktu vidējās piecpadsmit gadu vērtības - vidējais ievas ziedēšanas sākums.

Klimata projekciju dati. Klimata projekciju dati ir iegūti no ES FP6 Integrêtā Projekta ENSEMBLES (Līguma numurs 505539) klimata projekcijām, un statistiski adaptēti lokālajiem novērojumiem (Sennikovs, Bethers 2009). Adaptētie dati ir sagatavoti ESF projekta „Starpnozaru zinātnieku grupas un modeḷu sistēmas izveide pazemes ūdeṇu pētījumiem" ietvaros, un pieejami LU portālā: https://www.puma.lu.lv/klimats/. Klimata projekciju dati aptver periodu no 1960. līdz 2010. gadam. Ir izmantots 16 dažādu klimatisko modelu ansamblis. Klimatiskie modẹ i gan pagātnes, gan nākotnes periodam laika apstākḷus raksturo klimatiskā izpratnē - reālajam, novērotajam klimatam atbilst daudzgadu vidējās modelētās vērtības, ko var izmantot tendenču izvērtējamam nevis laika apstākḷu prognozēšanai.

Fenologiskais modelis. Fenologiiskās fāzes aprēķināšanai pētījumā ir izmantots modificēts termālā laika (grādu dienu) jeb aktīvās temperatūras summas modelis. Modelī pieņemts, ka augu attīstība notiek, ja gaisa temperatūra pārsniedz kritisko vērtību, pie tam attīstības ātrums ir proporcionāls temperatūrai. Fenologiskā fāze iestājas, kad nepieciešamā aktīvās temperatūras jeb grādu dienu summa tiek sasniegta. Aktīvās temperatūras summu aprēḳina saskaitot grādu vērtības, kas pārsniedz bāzes temperatūru noteiktā laika intervālā (stundas, diennaktis u.c.). Aktīvās temperatūras summas mērvien̄iba nav strikti definēta, to var raksturot kā grādi dotajam laika intervālam (piemēram, ' diennakts). Pêtījumā izmantojam fenoloğisko modeli DDcos (Kalvāns et al. 2014; Herms 2004), kur diennakts gaisa temperatūras gaita tiek aproksimēta ar sinusoīdas līkni, kuras ekstrēmās vērtības atbilst diennakts minimālajai un maksimālajai gaisa temperatūrai. Pieņemts, ka bāzes temperatūra ievu ziedēšanai ir $3.4^{\circ} \mathrm{C}$ un nepieciešamā aktīvās temperatūras summa ir $214^{\circ}$ diennakts. Atskaites punkts aktīvas temperatūras aprēḳināšanai ir attiecīgā gada 1. janvāris. 


\section{Rezultāti}

Parastās ievas Padus racemosa ziedēšana pirms 100 gadiem (laika periods 1927.-1940. gads). Pētījumā analizētas A. Zirn̄̄ša (1956) fenoloǵisko novērojumu piecpadsmit gadu (no 1927. līdz 1940. gadam 58 Latvijas punktos) datu vidējās vērtības, kas apkopotas A. Zirnīša rakstā.

Laika periodā no 1927. līdz 1940. gadam ievas ziedēšanas sākums novērots 17. maijā ar ievērojamām lokālām atšķirīibām, tā, piemēram, no analizētajiem punktiem, visvēlāk ievas ziedēšana fiksēta Liepājā, Vējavā (23. maijs) un Kolkasragā - 29. maijā; visagrāk - Iecavā (10. maijs) un Jelgavā (12. maijs). Ievas ziedēšana visā teritorijā iestājusies vidēji divu nedēlu intervālā. Fenoloǵiskais pavasaris Latvijā iestājas virzienā no DR uz ZA, tomēr analizētajā periodā š̄i sakarība neparadās: agrāk fāze vērojama Latvijas D, centrālajos rajonos. Tomēr izteikti redzama Baltijas jūras ietekme, jo piekrastes punktos, piemēram, Kolkasragā ievas zied 12 dienas vēlāk nekā vidēji Latvijas teritorijā.

Ilgtermina pārmainas (1927.-1935. gads un 1959.-2016. gads). Datu pieejamības dēl, analizēti trīs novērojumu punktu dati, atsevišķos gados izmantotas apvienotās datu kopas, piemēram, Dobele-Ukri vai Atašiene-Varakḷāni.

Analizējot ilgtermiņa datu rindu, konstatēts, ka vidēji ieva zied 12. maijā. No trīs analizētājiem punktiem - Dobele, Liepāja, Atašiene - agrāk ievas ziedēšana notiek Dobelē (11. maijā), vēlāk Liepājā - 14. maijā.

Ilgtermiṇa trends ir negatīvs, t.i., fāze iestājas vidēji agrāk, sakarība ir būtiska un statistiski ticama ( $\mathrm{r}$ Atašiene $=-0,46, \mathrm{r}$ Liepāja $=-0.58, \mathrm{r}$ Dobele $=-0.52)$. Laika periodā no 1959. līdz 1982. gadam var vērot pozitīvu tendenci, t.i., fāzei bija raksturīgi iestāties vēlāk, tomēr pēc 20.gs. 80. gadiem fāzes trends kḷuvis negatīvs.

Visagrākās vērtības gan ievu ziedēšanai, gan daudzām citām pavasara fāzēm visā Latvijas teritorijā bija novērotas 1990. gadā, kad, agrās fāzes, piemēram, lazdas, baltalkšņa ziedēšana fiksēta jau janvāra beigās nevis marta sākumā (atsevišķās vietās fāze iestājas pat 2 mēnešus agrāk kā vidēji). Ievas ziedēšana 1990. gadā novērota jau 16. aprīlī Dobelē, 21. aprīlî̀ Liepājā un 25. aprīlì Atašienē, kas ir gandrīz mēnesi agrāk. Aprīla beigās ieva ziedējusi arī 2000., 2008. un 2014. gadā. Vēlie gadi, kad novērotajās vietās ieva ziedējusi vien maija beigās, ir bijuši 1929., 1979., 1987. un 1980. gads.

Ja analizē novirzes no vidējām vērtībām, tad izteikti negatīvās jeb agrās vērtības ir raksturīgas perioda beigu posmam.

Sagaidāmais ievas ziedēšanas laiks vidējā un tālajā nākotnēe. Klimata zinātnē projekcijās bieži raksturo tuvās, vidējās un tālās nākotnes klimatu. Pētījumā apskatītas vidējās nākotnes (līdz 2050. gadam) un tālās (līdz 2100. gadam) klimata projekcijas un iespējamās ievas ziedēšanas laika pārmaiņas. 

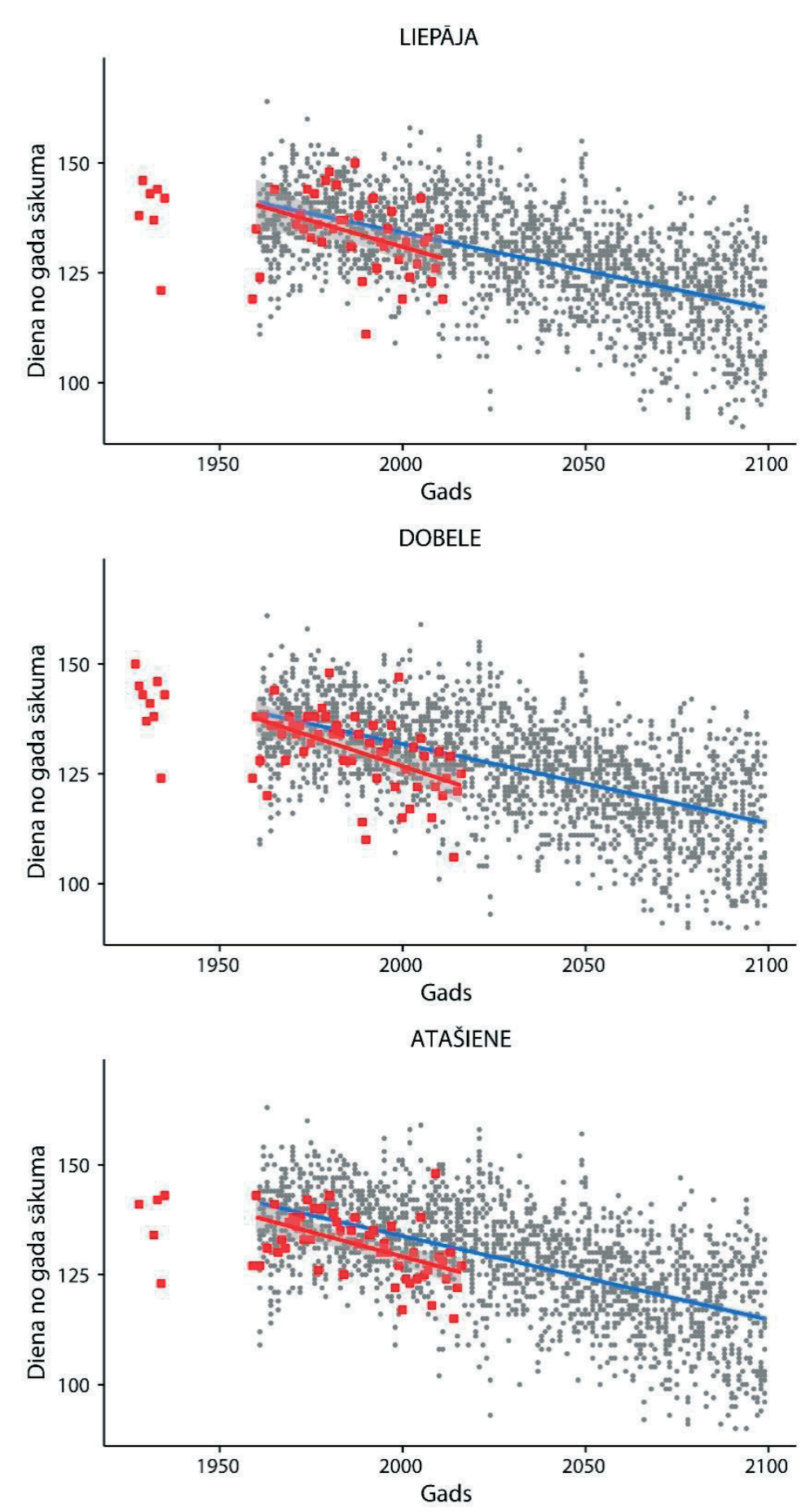

1. attēls. Parastās ievas Padus racemosa ziedēšanas sākums Liepājā, Dobelē un Atašienē laika periodā no 1927. līdz 1935. gadam; no 1959. līdz 2016. gadam (reālie novērojumi atzīmēti ar sarkanu) un aprēḳinātās vērtības no ENSEMBEL klimatisko modeḷu datiem (1960.-2100. gads). Uz y ass - diena no gada sākuma

Projekcija veikta trīs novērojumu punktiem, kuros pieejami ilgtermiņa fenologiisko novērojumu dati. Fāzes iestāšanās vidējā gada diena ir aprēķināta pēc lineārā regresijas vienādojuma laika intervālam par ko ir pieejami novērojumu dati. Vidējais novērotais ievas ziedēšanas laiks ir sistemātiski 3 līdz 5 dienas (1. tabula) agrāks, salīdzinot ar modelētajiem datumiem. Tomēr iestāšanās vērtību tendences 
1960.-2010. gada periodam (pieejami gan fenologisko novērojumu, gan klimata projekciju dati) ir līdzīgas (1. attēls), kas l̦auj izdarìt pieņēmumu, ka arī nākotnes klimatu modelis ataino ar līdzvērtīgu precizitāti.

1. tabula. Novērotā (faktiskā) un modeḷu ansambḷa aprēḳinātā vidējā ievas ziedēšanas fāzes iestāšanās (diena no gada sākuma)

\begin{tabular}{|l|l|l|l|l|l|l|l|l|l|l|}
\hline \multirow{2}{*}{ Stacija } & \multicolumn{1}{l}{ 1960. gads } & \multicolumn{2}{l|}{ 1990. gads } & \multicolumn{2}{l|}{ 2016. gads } & \multicolumn{2}{l|}{ 2050. gads } & \multicolumn{2}{l|}{ 2100. gads } \\
\cline { 2 - 11 } & Nov. & Mod. & Nov. & Mod. & Nov. & Mod. & Nov. & Mod. & Nov. & Mod. \\
\hline Atašiene & 138 & 142 & 131 & 136 & 126 & 131 & NA & 124 & NA & 114 \\
\hline Dobele & 138 & 139 & 129 & 134 & 122 & 129 & NA & 122 & NA & 113 \\
\hline Liepāja & 140 & 141 & 133 & 136 & 127 & 131 & NA & 125 & NA & 116 \\
\hline
\end{tabular}

Nov. - novērojumi

Mod. - modelis
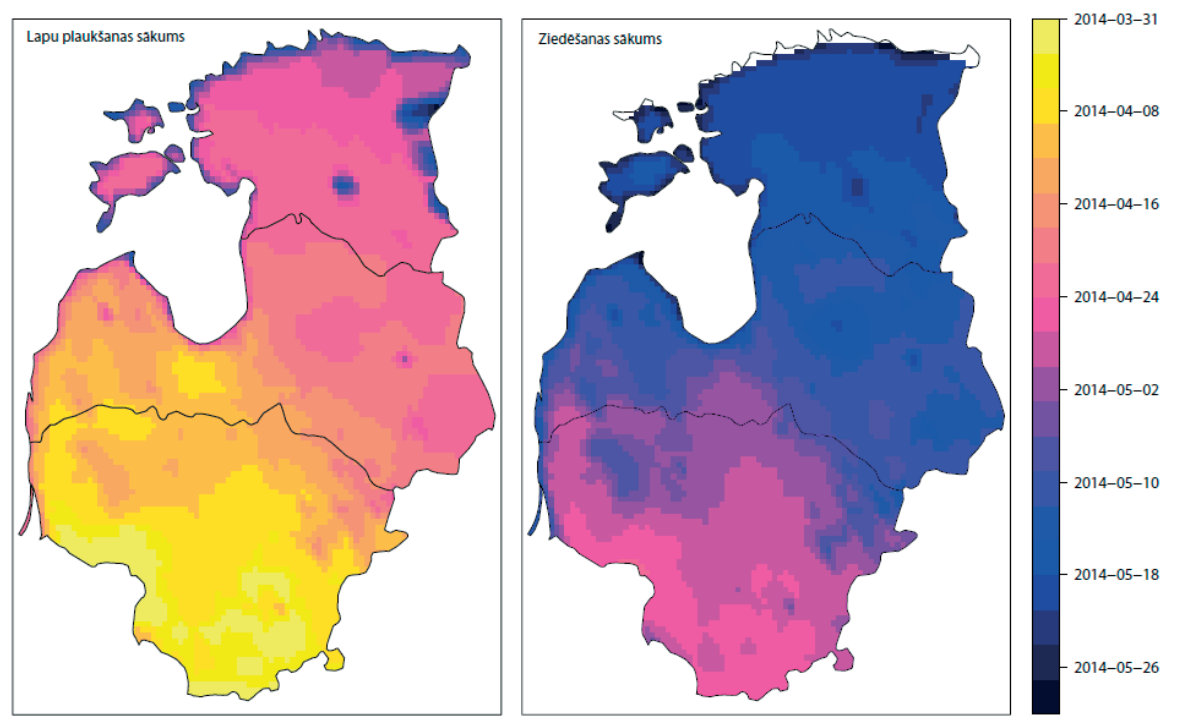

2. attēls. Parastās ievas Padus racemosa lapu plaukšanas un ziedēšanas sākuma regeionālās pārmaiṇas (2014. gada piemērs; modelētie dati, aprēkininos izmantotas aktīvās temperatūras summas)

Ilgtermiṇa fenologisko datu analīze liecina, ka vidēji ievas ziedēšana novērota 12. maijā, kas ir 132 dienas no gada sākuma. Modeḷa dati rāda, ka ievas ziedēšanas laiks mainīsies līdz pat 20 dienām tālajā projekcijāa, un 8-10 dienas - vidējā nākotnē (līèz 2050. gadam). Atašienē ievas ziedēšana fiksēta 12. maijā (132 dienas), 2050. gadā tiek prognozēts, ka ievas ziedēs nedēḷu agrāk (124 dienas), savukārt 2100. gadā - 18 dienas agrāk, t.i., 24. aprīlī.

Izmantojot meteoroloǵisko modeḷu datus var modelēt arī, lai fenoloǵisko fâzu iestāšanās laika reǵionālo sadalījumu (2. attēls).

Fenolog̣iskais pavasaris Baltijas teritorijā iestājās DR-ZA virzienā aptuveni viena mēneša intervālā (2. attēls). Fenologiisko făžu iestāšanās laiku ietekmē gan Baltijas jūras tuvums (Kolkasraga apkārtnē, Igaunijas $\mathrm{Z}$ dạ̦ā fāze iestājas vēlāk), gan reljefs (augstienēs - vēlāk), gan mikroklimatiskie faktori. 


\section{Secinājumi}

Fenolog̣isko fāžu iestāšanās laiks pēdējos 50 gados būtiski mainījies. Pavasara un vasaras fāzēm ir tendence sākties agrāk, savukārt rudens fāžu pārmaiņu raksturs ir lokāls ir atsevišķas teritorijas, kur koku lapu krāsošanās un krišana iestājas vēlāk, atsevišķās agrāk. Jo fāze iestājas agrāk, jo lielākas ir fiksētās pārmaiņas, piemēram, lazdas un baltalkšņa ziedēšanas sākums Latvijas teritorijā iestājas vairāk nekā mēnesi agrāk nekā 20.gs. vidū.

Ievas ziedēšana 20.gs. sākumā iestājusies vidēji 17. maijā, savukārt 20.gs. beigās vidēji 12. maijā. Līdzīgi kā visām pavasara fāzēm, iestāšanās trends ir negatīvs, t.i., fāze iestājas agrāk.

Pêtījumā izmantotais modificētais termālā laika (grādu dienu) jeb aktīvās temperatūras summas modelis ir labs indikators nākotnes projekciju modeliem, kā arī l̦auj detāli raksturot reǵionālās atškinirības.

Modelētās vērtības liecina, ka ievas ziedēšanas trends būs negatīvs un fāze iestāsies agrāk: vidējā nākotnē (līdz 2050. gadam) iespējams līdz pat 8 dienām agrāk, savukārt tālajā nākotnē līdz pat 20 dienām agrāk. Tomēr jāṇem vērā, ka pētījumā ir izmantots vienkāršs aktīvās temperatūras summas modelis (nenemot vērā tādus fiziologiiskus apstākḷus kā koka miera periods). Iespējams, gadsimta beigās, iestājoties daudz siltākām ziemām, ievu augšana pavasarī aizkavēsies, jo koki atradīsies miera periodā, kura pārtraukšanai nebūs sasniegti nepieciešamie apstākḷi - laika periods ar pietiekami zemu temperatūru.

\section{Pateicības}

Publikācija tapusi ar LU zinātnes bāzes finansējuma projekta "Klimata pārmaiṇas un dabas resursu ilgtspējīga izmantošana" (Nr. ZD2016/AZ03 ) daḷēju atbalstu.

\section{Atsauces}

Herms, D. (2004). Using degree-days and plant phenology to predict pest activity. Krischik, V., Davidson, J. (eds) IPM (Integrated Pest Management) of Midwest Landscapes, Minnesota Agricultural Experiment Station Publication 58-07645. 49-59.

Kalvāne, G. (2011). Fenologiskās izmaiņas un to ietekmējošie klimatiskie faktori. Rīga, LU Akadēmiskais apgāds. 166

Kalvāns, A., Bitāne, M., Kalvāne, G. (2014). Forecasting plant phenology evaluating the phenological models for Betula pendula and Padus racemosa spring phases, Latvia. International Journal of Biometeorology 59 (2), 165-179

Koch, E., Bruns, E., Chmielewski, F. M., Defila, C., Lipa, W., Menzel, A. (2009). Guidelines for plant phenological observations. WMO Sk. 01.02.2018. Pieejams: https://library.wmo.int/pmb_ged/wmo-td_1484_en.pdf

Sennikovs, J., Bethers, U. (2009). Statistical downscaling method of regional climate model results for hydrological modelling. 18th World IMACS / MODSIM Congress (July), 3962-3968.

Zirnītis, A. (1956). Daži pētījumi par Latvijas PSR bioklimatu. Latvijas Valsts Universitātes zinātniskie raksti, VII sēj.,G̣eogrāfijas zinātnes, I, 4

\section{Summary}

Phenological data are often used in climate change research, both to reconstruct the climate of the past and assess the potential impact of future climate. The long-term data flowering data of the bird cherry 
Padus racemosa in Latvia is analysed and possible trends future trends are modelled using the degree day (active temperature sum) and the ENSEMBLES climate data set. During the last 50 years the average dates of the bird cherry flowering have shifted by a week - they occur earlier. Negative flowering trends are expected for future as well: model data shows that by the end of the 21th century in Latvia the bird cherry flowering will take place by the end of April and not in middle of May as at present day. 